\title{
Erratum to: Neurobehavioral deficits and brain oxidative stress induced by chronic low exposure of persistent organic pollutants mixture in adult female rat
}

\author{
Asma Lahouel $^{1}$ - Mohamed Kebieche ${ }^{1,5} \cdot$ Zohra Lakroun $^{1} \cdot$ Rachid Rouabhi $^{2}$. \\ Hamadi Fetoui $^{3} \cdot$ Yassine Chtourou $^{3} \cdot$ Zama Djamila $^{4} \cdot$ Rachid Soulimani $^{5}$
}

Published online: 7 July 2016

(C) Springer-Verlag Berlin Heidelberg 2016

Erratum to: Environ Sci Pollut Res

DOI 10.1007/s11356-016-6913-9

Unfortunately, the original publication of this paper contains several inaccuracies:

1. - The cited reference in introduction section (Ardzivian et al., 2012) to be changed on (Elnar et al., 2012) And to be in the reference section as following:

Elnar AA, Diesel B, Desor F, Feidt C, Bouayed J, Kiemer AK, Soulimani R (2012) Neurodevelopmental and behavioral toxicity via lactational exposure to the sum of six indicator non-dioxinlike-polychlorinated

The online version of the original article can be found at http:// dx.doi.org/10.1007/s11356-016-6913-9.

Mohamed Kebieche

kebiechem2016@gmail.com

1 Laboratory of Cellular and Molecular Biology, University of Jijel, Jijel, Algeria

2 Faculty of SESNV, Applied Biology Department, University of Tebessa, Tebessa, Algeria

3 Toxicology-Microbiology and Environmental Health Unit (UR11ES70), University of Sfax, Sfax, Tunisia

4 Department of Animal Biology, University of Mentouri 1, Constantine, Algeria

5 Université de Lorraine, Unité de Recherche Animal et Fonctionnalités des Produits Animaux (UR AFPA), EA3998, INRA USC 0340, Micropolluants et Résidus de la Chaine Alimentaire (MRCA), Neurotoxicologie Alimentaire et Bioactivité, BP 4102, 57040 Metz, France biphenyls ( $\Sigma 6 \mathrm{NDL}-\mathrm{PCBS}$ ) in mice. Toxicology 299:44-54.

- The cited reference in introduction section (Guillemette et al., 2012) to be changed on (Crépeaux et al., 2012) and to be in the reference section as following:

Crépeaux G, Bouillaud-Kremarik P, Sikhayeva N, Rychen G, Soulimani R, Schroeder $H$ (2012) Late effects of a perinatal exposure to a 16 PAHmixture: increase of anxiety-related behaviours and decrease of regional brain metabolism in adult male rats. Toxicol Lett 211:105-113.

2. In the introduction section, it has been mentioned: “..., while lactational exposure to a representative mixture of $P C B$ found in contaminated fish matrices has induced oxidative stress and apoptosis in juveniles...". Nevertheless, in this cited paper, nor the oxidative status neither the cell viability were evaluated in juvenile mice. The results concerning the oxidative status were only published in another paper, in which no significant effects were observed regarding the oxidative stress in the cerebellum of juvenile mice whose mothers were exposed during lactation to the mixture of the 6 NDL-PCBs.

3. The section 3 of the erratum is commented in answer 2 and the reference "a." is well corrected in answer " 1 " but the reference " $b$ " reported in section 3 has never been cited in our article simply our article was submitted in 2015 Jan, so before the date of the appearence of this reference, $2015 \mathrm{Feb}$.

By the way, I inform the editor that the oxidative stress, epigenetic effect and apoptosis are known to be the impact effects of PCBs and POPs well known before the publication of the reference cited in our article. The PCBs Cause oxidative stress and Apoptosis in juvenile and adult 
rats reported in many papers such the following references:

- Selvakumar K1, Bavithra S, Suganthi M, Benson CS, Elumalai P, Arunkumar R, Krishnamoorthy G, Venkataraman P, Arunakaran J. (2012) Protective role of quercetin on PCBs-induced oxidative stress and apoptosis in hippocampus of adult rats. Neurochem Res 37(4):708-21.

- Sarah M. Dickerson1, Stephanie L. Cunningham1, and Andrea C. Gore. (2011) Prenatal PCBs Disrupt Early Neuroendocrine Development of the Rat HypothalamusToxicol Appl Pharmacol 252(1):36-46. doi:10.1016/j.taap.2011.01.012.

- Anne Dreiem, Sidsel Rykken, Hans-Joachim Lehmler, Larry W. Robertson, and Frode Fonnum (2009) Hydroxylated polychlorinated biphenyls increase reactive oxygen species formation and induce cell death in cultured cerebellar granule cells Toxicol Appl Pharmacol 240(2):306-313.
- Dongren Yang and Pamela J. Lein (2010) Polychlorinated biphenyls increase apoptosis in the developing rat brain. Curr Neurobiol 1(1):70-76.

- $\quad$...and many others

4. The name of the institution $\mathrm{N}^{\circ} 5$ is incorrect. It has to be as follow: "Université de Lorraine, Unité de Recherche Animal et Fonctionnalités des Produits Animaux (UR AFPA), EA3998, INRA USC 0340, Micropolluants et Résidus de la Chaine Alimentaire (MRCA), Neurotoxicologie Alimentaire et Bioactivité, BP 4102, 57040 Metz, France ». Corrected above in affiliation $N^{\circ} 5$

5. Dr. Kebieche is only affiliated to the institution $\mathrm{N}^{\circ} 1$. Dr. KEBIECHE is affiliated also to the institution $\mathrm{N}^{\circ} 5$ as he has completed his doctoral thesis in affiliation N 5 under the direction of Prof. Rachid SOULIMANI, food neurotoxicity team leader and continue his scientific visits for over 10 years through scientific cooperation which has given many copublications since 2009. 